\title{
The Influence of Factors of Breastfeeding and Food Consumption on Stunting Incidence among Preschool Children in Keerom District, Papua Province, Indonesia
}

\author{
I. Rai Ngardita ${ }^{1 *(D)}$, Ratih Nurani Sumardi ${ }^{1}$, Sanya Anda Lusiana ${ }^{1}$ (D), I Komang Agusjaya Mataram ${ }^{2}$ (D), Andi Eka Yunianto ${ }^{3}$ (D) \\ ${ }^{1}$ Department of Nutrition, Health Polytechnic of Health-Ministry, Jayapura, Indonesia; ${ }^{2}$ Department of Nutrition, Health \\ Polytechnic of Health-Ministry, Denpasar, Indonesia; ${ }^{3}$ Department of Nutrition, Faculty of Health Science, Siliwangi University, \\ Tasikmalaya, Indonesia
}

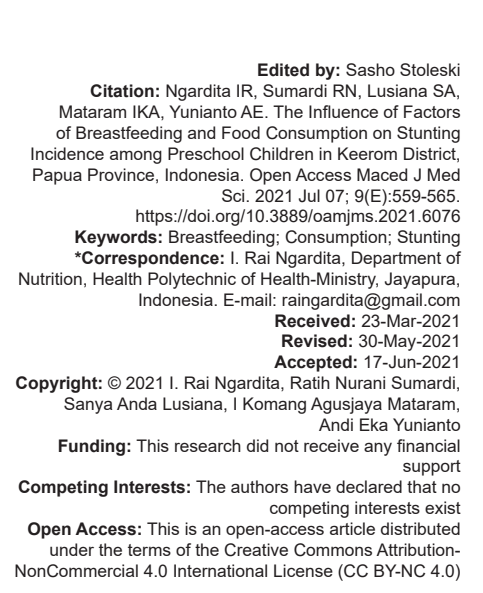

\section{Abstract}

BACKGROUND: Stunting is a nutritional problem due to linear growth failure in children under five, resulting in future health problems. Papua has a prevalence of stunting in children under five of $17.8 \%$ in 2018 .

AIM: This study aimed to analyze the influence of breastfeeding and consumption factors on the incidence of stunting in Keerom District, Papua Province.

METHOD: This study was a cross-sectional design. The sample in this study was 324 toddlers. Characteristics data and breastfeeding were obtained by interviewing parents. In contrast, data on the consumption of children under five were obtained using the Food Recall. Nutritional status was calculated using the Z-score obtained from measurements of body weight and height of children under five. SEM analysis was used to analyze breastfeeding and consumption factors on children's nutritional status under five.

RESULT: The study results based on consumption $(p<0.05 ; r=0.052)$ and breastfeeding $(p<0.05 ; r=-0.015)$ had a relationship with the incidence of stunting.

CONCLUSION: There was a significant effect of consumption and breastfeeding factors on the incidence of underfive stunting.

\section{Introduction}

The first global nutrition goal for 2030 by the World Health Assembly is to reduce the proportion of children under five who stunted by $40 \%$ [1]. Stunting reflects the condition of failure to thrive in children under five due to chronic malnutrition. It is characterized by a height or weight that is not sufficient for the growth reference standard, especially at 3-5 years [2]. This linear growth failure is a marker of various pathological disorders associated with increased morbidity and mortality, loss of physical growth potential, decreased neurodevelopmental and cognitive function, and an increased risk of chronic disease in adulthood [3].

Chronic malnutrition occurs when the baby is in the womb, but stunting will be seen after the baby is 2 years old. Therefore, the first 1000 days of life become the main focus because it determines the level of physical growth, intelligence, and productivity in the future. The 2013 Riskesdas results show that around $37 \%$ (9 million) children are stunted, and Indonesia ranks fifth with the world's highest stunting prevalence. Toddlers and Baduta who are stunted will be more susceptible to disease and are at risk of decreasing productivity levels [4]. If this situation is not resolved, it can affect Indonesia's development performance, economic growth, poverty, and inequality. In Indonesia, stunted children are experienced by poor or underprivileged families and non-poor families.

According to $\mathrm{WHO}$, the causes of stunting in children are divided into two factors: direct and indirect causes. The immediate causes are family factors (pregnancy and environment), inadequate feeding (poor quality of food, wrong feeding, and sanitation), breastfeeding practices, and infections. Food consumption is one of the causes of stunting in children under five. Toddlers need quality nutrient-rich foods that are obtained by eating a variety of foods [5], [6], [7]. Poor diet results in malnutrition in children, further exacerbated by micronutrient deficiencies, which can worsen the nutritional status and level of health of children [8]. Besides, breastfeeding has been identified 
as a modifiable health behavior to protect children from stunting [9], [10]. Lack of consumption of breast milk can have an effect on increasing the risk of growth and development in preschool children [11].

Proper breastfeeding is the most effective step to meet children's nutritional adequacy. The nutritional composition in breast milk fulfills the child's dietary needs and positively influences children's growth [12]. Early initiation of breastfeeding may prevent and reduces the risk of stunting, while delaying breastfeeding initiation resulted in a 1.3 times higher risk of stunting [8]. It is hoped that breastfeeding for a minimum of 6 months or exclusive breastfeeding is also essential to reduce stunting prevalence in children under five [9].

Papua Province is one of the provinces that has a higher stunting rate than the national one. Riskesdas 2018 show the prevalence of nutritional status in children aged $0-23$ months (Baduta) is very short at $15.1 \%$, while in Indonesia, it is $12.8 \%$. In Papua, it was $18.9 \%$, and Indonesia $17.1 \%$. The prevalence of nutritional status in very short children aged $0-59$ months (toddlers) is $15.3 \%$, while in Indonesia, it is $11.5 \%$. The prevalence of stunting is $17.8 \%$; this figure is lower than in Indonesia, which is $19.3 \%$ [13].

In 2018 the National Team for the Acceleration of Poverty Reduction (TNP2K), the Coordinating Ministry for Human Development and Culture, and Bapenas set priority districts/cities for handling stunting in Indonesia. In 2019 (phase II of handling stunting), the priority districts/towns in Papua Province are Asmat, Biak Numfor, Boven Digul, Deyai, Keerom, and Yapen Islands [14]. Keerom District is one of the districts in Papua Province, located south of Jayapura City, and can be reached by land route. The prevalence of stunting in the Keerom District is $10.45 \%$, with a poverty rate of $45.11 \%$. Keerom District consists of 7 districts and 61 villages. Keerom District is one of the districts included in phase II in handling stunting in the Papua region.

Based on the description above, it is necessary to analyze the risk factors associated with stunting problems, especially in children under five in Keerom District. These factors are then analyzed statistically using structural equation modeling (SEM) to assess the strength of their relationship with one another. The results of this SEM analysis will be used to formulate a model for the occurrence of nutritional problems in children under five, which link stunting with family and household factors. Complementary feeding is inadequate in breastfeeding practices and infectious diseases. With this model's compilation, it is hoped that policyholders at the Keerom District level, such as the Health Office, will focus more on developing specific nutrition problem management programs based on risk factor analysis in each working area of Keerom District.

\section{Methods}

This research received ethical approval from the health research ethics committee of the Health Polytechnic of the Ministry of Health Yogyakarta with the number: e-KEPK/POLKESYO/0371/X/2019. This research was conducted for 5 months, starting from August to December 2019. This type of research was a cross-sectional design. The study was located in Keerom District, Papua Province, one of the 160 priority regions for stunting intervention with a prevalence of $10.45 \%$. The sampling technique was carried out by stratified random sampling. Of the 9 stunting locus areas in the Keerom region, three regions were randomly selected, then $30 \%$ of the under-five population in the three regions were selected again. About 324 children under five were involved as samples. The inclusion criteria in this study including (a) children aged 6-59 months, (b) having a biological mother, (c) parents willing to participate in the study. The criteria for children under five, including (a) not sick or on outpatient treatment, (b) not at the research site at the time of the study, (c) under-fives with congenital disorders. The exclusion criteria were children under five who were sick or on outpatient treatment/not at the research location at the time of the study, (b) under-fives with congenital disorders (c) staying at the research location for $<6$ months. The variables examined in this study were nutritional status as the dependent variable and breastfeeding and consumption as independent variables.

\section{Socio-demographic characteristics}

The socio-geographical characteristics data in this study consisted of toddler characteristics and parental characteristics. The data on children under five's characteristics gender, age, height, and parental characteristics included age, education, and occupation.

\section{Breastfeeding practices}

Breastfeeding data in this study consisted of early breastfeeding initiation practices, exclusive breastfeeding, and duration of breastfeeding.

\section{Consumption}

Consumption data were collected using the $1 \times 24$ hour food recall method for two days. This study's consumption data consisted of energy, protein, Vitamin A, iron, iodine, and zinc. Nutritional adequacy is calculated directly by comparing the nutritional adequacy rate. Furthermore, the level of nutritional adequacy is obtained by comparing the amount of consumption of these nutrients with their adequacy [15]. The following is the formula for the adequacy of nutrients used: 
$\mathrm{TKGi}=(\mathrm{Ki} / \mathrm{AKGi}) \times 100 \%$

Note:

TKGi $=$ The level of adequacy of the nutrient $\mathrm{i}$

$\mathrm{Ki}=$ Consumption of nutrients $\mathrm{i}$

$\mathrm{AKGi}=$ Adequacy rate of the nutrient $\mathrm{i}$.

\section{Nutritional status}

The nutritional status of children under five is determined based on the WHO Growth Child standards 2006 and calculated by the WHO Anthro software (version 3.2.2, January 2011). Toddler status data includes: height-for-age z-score (HAZ), Weight-forage z-score (WAZ), Weight-for-height z-score (WHZ), and BMI-for-age z-score (zBMI). The following cutoffs as defined by the WHO were used: stunted: <-2 HAZ (moderate stunted: $-3 \leq \mathrm{HAZ}<-2$; severe stunted: $\mathrm{HAZ}<-3)$; acute malnutrition based on WHZ score: <-2 WHZ (acute malnutrition: $-3 \leq \mathrm{WHZ}<-2$; severe acute malnutrition: $\mathrm{WHZ}<-3)$.

\section{Data analysis}

The data that have been collected was processed according to the type of variable. The process of entering data (data entry) using a computer. To determine the strength of the relationship between variables and to compile a stunting model in Keerom District, the AMOS 20 structural equation modeling (SEM) analysis was used.

Nutritional status indicators were body weight for age (NS1), height for age (NS2), weight for height (NS3), and body mass index for age (NS4). Indicators of breastfeeding were early breastfeeding (BF1), exclusive breastfeeding (BF2), and duration of breastfeeding (BF3). Consumption indicators were energy consumption (CF1), protein (CF2), iron (Fe) (CF3), Vitamin A (CF4), zinc (Zn) (CF5), lodine (CF6), meal frequency (CF7), meal arrangement (CF8), and availability of foodstuffs (CF9).

\section{Results}

This research was conducted in Keerom Papua District. Specifically, the study was located in the Arso Kota and Arso III Community health centers (Puskesmas) areas. It involving five villages, namely Arso Kota, Jaifuri, Gudang Garang, Alang-Alang, and the sample in this study was 324 samples. Respondents in this study were mothers of toddlers. This study's sample was toddlers with no sick criteria and was in the study location. The distribution of samples according to the characteristics can be seen in the following table.
Table 1 shows that the distribution of male and female respondents was almost the same. The sample's mean age was 27.77 months (2 years three months), and the mean sample weight at birth was $3.30 \mathrm{~kg}$.

Table 1: Distribution of samples according to characteristics

\begin{tabular}{lll}
\hline Characteristics of the sample & f & $\%$ \\
\hline Gender & 165 & 50.9 \\
Male & 159 & 49.1 \\
Female & $27.77 \pm 14.82$ & \\
Age (months) (mean \pm SD) & $3.30 \pm 0.46$ & \\
Birth weight $(\mathrm{kg})($ mean \pm SD) & \\
\hline
\end{tabular}

Table 2 shows that the father's mean age was 34 years, and the mother's average age was 27 years. Most father's education was graduated from high school, and most mother's education was graduated from high school, the father's occupation mainly was self-employed, and the mother's job was not working (as a housewife).

Table 2: Distribution of the characteristics of the respondents' parents

\begin{tabular}{lll}
\hline Parental characteristics & $\mathrm{f}$ & $\%$ \\
\hline Age (mean \pm SD) (years) & $30.05 \pm 6.18$ & \\
Mother & $34.55 \pm 6.91$ & \\
Father & & \\
Mother education: & 12 & 3.7 \\
Not schooling & 4 & 1.2 \\
Not completing the elementary school & 30 & 9.3 \\
Graduated from elementary school & 6 & 1.9 \\
Not finishing junior high school & 43 & 13.3 \\
Graduated from junior high school & 15 & 4.6 \\
Not finishing high school & 140 & 43.2 \\
Graduated from high school & 74 & 22.8 \\
Completed the university education & & \\
Father education: & 5 & 1.5 \\
Not schooling & 8 & 2.5 \\
Not completing the elementary school & 26 & 8.0 \\
Graduated from elementary school & 5 & 1.5 \\
Not finishing junior high school & 47 & 14.5 \\
Graduated from junior high school & 13 & 4.0 \\
Not finishing high school & 155 & 47.8 \\
Graduated from high school & 65 & 20.8 \\
Completed the university education & & \\
Mother occupation: & 221 & 68.2 \\
No work & 13 & 4.0 \\
Farmer & 3 & 0.9 \\
Labor & 34 & 10.8 \\
Entrepreneur & 26 & 8.0 \\
Civil servants & 11 & 3.4 \\
Traders & 15 & 4.6 \\
Private employees & & \\
Father occupation: & 9 & 2.8 \\
No work & 65 & 0.3 \\
Farmer & 18.1 \\
Breeder & 159 & 5.6 \\
Labor & 38 & 49.1 \\
Entrepreneur & 8 & 2.5 \\
Civil servants & 26 & 8 \\
Traders & & \\
Private employees & & \\
\hline & & \\
& &
\end{tabular}

Table 3 shows that most of the samples $(84.8 \%)$ had a very good early breastfeeding practices status. About $93.2 \%$ of the samples were very good at exclusive breastfeeding. In comparison, $81.8 \%$ of the samples had a very good breastfeeding duration. The highest sample energy intake was in the fairly good category $(36.7 \%)$. The most protein consumption was in the very good category $(84.0 \%)$. Most samples had Vitamin A in the very good category (67.0\%). The highest sample of $\mathrm{Fe}$ intake was in a low category (46\%). The highest category of iodine intake was very low $(82.1 \%)$. Nutritional status by bodyweight/age index 
Table 3: Distribution of samples according to breastfeeding, consumption, and nutritional status

\begin{tabular}{|c|c|c|}
\hline Indicators & $\mathrm{n}$ & $\%$ \\
\hline \multicolumn{3}{|l|}{ Breastfeeding } \\
\hline \multicolumn{3}{|l|}{ Early breastfeeding } \\
\hline Good (breastfed immediately after birth) & 273 & 84.3 \\
\hline Less (indirect breastfeeding was born) & 51 & 15.7 \\
\hline \multicolumn{3}{|l|}{ Exclusive breastfeeding } \\
\hline Good (6 months) & 302 & 93.2 \\
\hline Less (<6 months) & 22 & 6.8 \\
\hline \multicolumn{3}{|l|}{ Duration of breastfeeding } \\
\hline Good (2 years) & 265 & 81.8 \\
\hline Less $(<2$ years $)$ & 59 & 18.2 \\
\hline \multicolumn{3}{|l|}{ Energy Consumption } \\
\hline Good $(1300 \leq R D A \leq 1400) \mathrm{kcal}$ & 119 & 36.7 \\
\hline Less $($ RDA $<1300) \mathrm{kcal}$ & 205 & 63.3 \\
\hline \multicolumn{3}{|l|}{ Protein Consumption } \\
\hline Good $(20 \leq R D A \leq 25) \mathrm{g}$ & 272 & 84.0 \\
\hline Less $($ RDA $<20) g$ & 52 & 16.0 \\
\hline \multicolumn{3}{|l|}{ Vitamin A Intake } \\
\hline Good $(400 \leq R D A \leq 450) R E$ & 217 & 67.0 \\
\hline Less $(\mathrm{RDA}<400) \mathrm{RE}$ & 107 & 33.0 \\
\hline \multicolumn{3}{|l|}{ Fe Intake } \\
\hline Good $(7 \leq \mathrm{RDA} \leq 10) \mathrm{mg}$ & 149 & 46.0 \\
\hline Less $(\mathrm{RDA}<7) \mathrm{mg}$ & 175 & 54.0 \\
\hline \multicolumn{3}{|l|}{ lodine Intake } \\
\hline Good $(90 \leq R D A \leq 120) \mathrm{mcg}$ & 58 & 17.9 \\
\hline Less $(\mathrm{RDA}<90) \mathrm{mcg}$ & 266 & 82.1 \\
\hline \multicolumn{3}{|l|}{ Zinc Intake } \\
\hline Good $(3 \leq \mathrm{RDA} \leq 5) \mathrm{mg}$ & 172 & 53.1 \\
\hline Less $(\mathrm{RDA}<3) \mathrm{mg}$ & 152 & 46.9 \\
\hline \multicolumn{3}{|l|}{ Bodyweight / Age } \\
\hline Good $(-2 \leq S D<2)$ & 304 & 93.8 \\
\hline Less (<-2 SD) & 20 & 6.2 \\
\hline \multicolumn{3}{|l|}{ Bodyheight / Age } \\
\hline Good $(-2 \leq S D<2)$ & 267 & 82.4 \\
\hline Less $(\mathrm{SD}<-2)$ & 57 & 17.6 \\
\hline \multicolumn{3}{|l|}{ Bodyweight/ Bodyheight } \\
\hline Good $(-2 \leq \mathrm{SD}<2)$ & 305 & 94.1 \\
\hline Less $(\mathrm{SD}<-2)$ & 19 & 5.9 \\
\hline \multicolumn{3}{|l|}{ BMI / Age } \\
\hline Good $(-2 \leq S D<1)$ & 307 & 94.8 \\
\hline Less $(S D<-2)$ & 17 & 5.2 \\
\hline
\end{tabular}

was $93.8 \%$ samples classified good categories, height/ age index was $82.4 \%$ sample in good categories, index weight/height was $94.1 \%$ sample in the good category, and BMI/Age index $94.8 \%$ was a very good category.

Analysis of nutritional status indicators (NS1, NS2, NS3, and NS4) was said to be able to explain the nutritional status variable if it had a critical ratio (C.R.) > 1.96 or a $p<0.05$. In other words, it can also be seen that the estimated loading value was $>0.5$. Table 4 shows that of the four indicators, three indicators had an estimated loading value $>0.5$, namely NS1, NS3, and NS4. It means that the three indicators were valid to explain the nutritional status variables used in model analysis. The breastfeeding indicator shows the three indicators, and all indicators had an estimated loading value of $>0.5$, namely $\mathrm{BF} 1, \mathrm{BF} 2$, and $\mathrm{BF} 3$. It means that the three indicators were valid to explain breastfeeding variables to be used in model analysis. The consumption indicator shows the six indicators. All of them were valid to explain the consumption variable used in the model analysis (Table 4).

The measurement model is part of the SEM model, consisting of a dependent variable or several independent variables and several indicator variables from each of these variables. After the measurement model was proven valid, the process was continued by carrying out a structural model, analyzing the relationship between the dependent and independent variables and between indicator variables.
Table 4: Confirmatory factor analysis indicators of nutritional status, breastfeeding, and consumption

\begin{tabular}{|c|c|c|c|c|}
\hline Indicators & Estimate & S.E. & C.R. ${ }^{* \star *}$ & $p$-value \\
\hline $\mathrm{NS}_{1}^{* \star}$ & 1.000 & & & \\
\hline NS2* & -0.579 & 0.458 & -1.266 & 0.205 \\
\hline $\mathrm{NS}^{* \star}$ & 4.800 & 1.385 & 3.466 & $* * *$ \\
\hline NS4 ${ }^{\star \star}$ & 3.884 & 1.011 & 3.841 & *** \\
\hline $\mathrm{BF} 1^{\star \star}$ & 1.000 & & & \\
\hline $\mathrm{BF}^{* *}$ & 1.171 & 0.279 & 4.202 & $* * *$ \\
\hline $\mathrm{BF} 2^{\star \star}$ & 1.296 & 0.421 & 3.079 & 0.002 \\
\hline CF2 & 0.721 & 0.100 & 7.242 & $* * *$ \\
\hline CF3 & 1.072 & 0.135 & 7.922 & *** \\
\hline CF4 & 1.099 & 0.128 & 8.556 & *** \\
\hline CF5 & 0.707 & 0.126 & 5.626 & *** \\
\hline CF6 & 0.279 & 0.085 & 3.291 & 0.001 \\
\hline CF1 & 1.000 & & & \\
\hline
\end{tabular}

Figure 1 illustrates the relationship between the dependent and between independent and indicator variables. SEM model looked at the dependent variable nutritional status (NS1, NS3, and NS4) and the independent variable consumption (CF1, CF2, CF3, CF4, CF5, and CF6), breastfeeding (BF1, BF2, BF3).

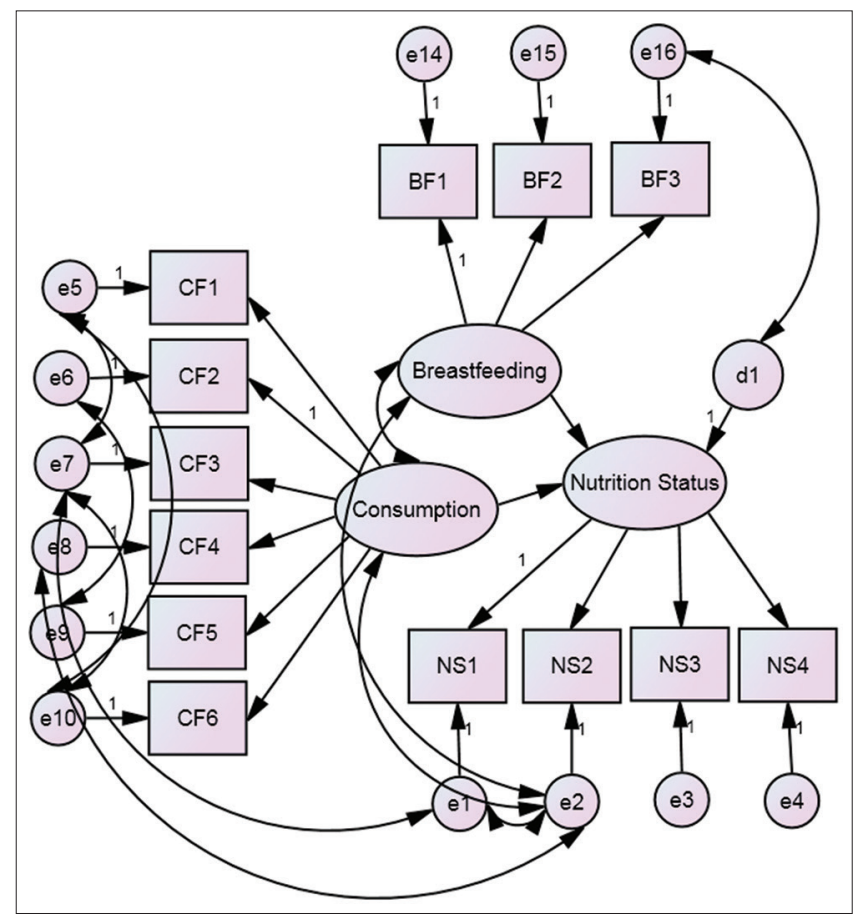

Figure 1: Respecification model of the relationship between dependent variables on nutritional status, independent variable of breastfeeding, and indicator variables

Table 5 shows the result based on the two methods of the model's feasibility test, FGI (Goodness of Fit Index) $\geq 0.90$ and AGFI (Adjusted Goodness of Fit Index) $\geq 0.80$. It shows that the goodness of fit index results of the model respecifications had met the required cut-off value, so the model was feasible (Table 5).

Table 5: Goodness of fit confirmatory index recpecification model of nutritional status, consumption, and breastfeeding

\begin{tabular}{llll}
\hline Fit Index & Cut-off value & Model results & Note \\
\hline GFI & $\geq 0.90$ & 0.974 & Feashible \\
AGFI & $\geq 0.80$ & 0.659 & Not Feashible \\
\hline
\end{tabular}

Table 6 shows with $p<0.05$ or column estimate with a value $>0.5$ shows the indicators $B F 1, B F 2$ and BF3. They could explain the independent variables of 
Table 6: Results of loading regression weights relationship between nutritional status and breastfeeding with indicators

\begin{tabular}{lllll}
\hline Dependent Variables, & Independent and Indicators & Estimate & p-value \\
\hline Nutrition Status & $<--$ & Breasfeeding & -.005 & 0.830 \\
Nutrition Status & $<--$ & Consumption & .013 & 0.438 \\
NS1 & $<---$ & Nutrition Status & 1.000 & - \\
CF2 & $<--$ & Consumption & 1.000 & - \\
NS3 & $<---$ & Nutrition Status & 4.818 & 0.000 \\
NS2 & $<---$ & Nutrition Status & -.646 & 0.000 \\
NS4 & $<---$ & Nutrition Status & 4.068 & 0.000 \\
CF1 & $<---$ & Consumption & 1.647 & 0.000 \\
BF3 & $<--$ & Breastfeeding & 1.195 & 0.000 \\
BF2 & $<--$ & Breastfeeding & 1.410 & 0.002 \\
BF1 & $<--$ & Breastfeeding & 1.000 & \\
CF6 & $<---$ & Consumption & .493 & 0.002 \\
CF5 & $<---$ & Consumption & .883 & 0.000 \\
CF4 & $<---$ & Consumption & 1.686 & 0.000 \\
CF3 & $<---$ & Consumption & 1.882 & 0.000 \\
\hline
\end{tabular}

breastfeeding. NS1, NS2, NS3, and NS4 indicators explained the dependent variable nutritional status. The indicators CF1, CF2, CF3, CF4, CF5, and CF6, explained the dependent variable consumption.

Table 7 shows breastfeeding and consumption factors explaining the weak relationship in nutritional status $(r=-0.015)$ and $(r=0.052)$. If the value of $r=-0.015$ were squared, a value of $0.03 \%$ would be obtained. It means that the breastfeeding factor of $0.52 \%$ explained the nutritional status factor. The remaining $99.97 \%$ was explained by a unique factor, error factor ( $d 1)$. For $r=0.052$, it was $0.27 \%$, means that the consumption factor was $0.27 \%$. It explained the nutritional status factor, while the remaining 99.73 was explained by a unique factor, error factor (d1).

Table 7: Results of loading standardized regression weights: dependent, independent, and indicator variables

\begin{tabular}{llll}
\hline $\begin{array}{l}\text { Dependent Variables } \\
\text { and Indicators }\end{array}$ & & $\begin{array}{l}\text { Dependent and } \\
\text { Independent Variables }\end{array}$ & Regression Coefficient (r) \\
\hline Nutrition Status & $<---$ & Breastfeeding & -0.015 \\
Nutrition Status & $<--$ & Consumption & 0.052 \\
NS1 & $<---$ & Nutrition Status & 0.203 \\
CF2 & $<---$ & Consumption & 0.516 \\
NS3 & $<---$ & Nutrition Status & 0.997 \\
NS2 & $<---$ & Nutrition Status & -0.082 \\
NS4 & $<---$ & Nutrition Status & 0.887 \\
CF1 & $<---$ & Consumption & 0.647 \\
BF3 & $<---$ & Breastfeeding & 0.422 \\
BF2 & $<---$ & Breastfeeding & 0.764 \\
BF1 & $<---$ & Breastfeeding & 0.374 \\
CF6 & $<---$ & Consumption & 0.244 \\
CF5 & $<---$ & Consumption & 0.336 \\
CF4 & $<---$ & Consumption & 0.680 \\
CF3 & $<---$ & Consumption & 0.716 \\
\hline
\end{tabular}

\section{Discussion}

1. The Relationship between Consumption Factors and Nutritional Status

Based on the confirmatory analysis factor, the consumption indicator ( $r=0.052$ ) or the consumption factor of $0.27 \%$ explained the nutritional status factor. The remaining 99.73 was defined by a unique factor, namely, error factor (d1). It causes the consumption factor to be further analyzed in the model structure analysis. In other words, the relationship between consumption factors can be analyzed directly with nutritional status.
Malnutrition is a severe health challenge factor in developing countries. Poor child feeding practices have been identified as a significant cause of stunting. Dietary diversity is one of the core indicators when assessing children's feeding practices and nutrition in obtaining nutrients that are essential for growth and development [16]. There were 12 foods important for children under five, namely (1) cereals, (2) spices condiments and beverages, (3) sweets, (4) oil and fats, (5) meat, (6) fruit, (7) vegetables, (8) milk and milk products, (9) tuber and roots, (10) legumes, nuts, and seeds, (11) eggs, (12) fish and other seafood [17]. Previous research had shown that most Indonesian children consume tuber vegetables and low consumption of fruit and dairy products [18].

Diversity in food consumption is a proxy for dietary quality and nutritional adequacy. Dietary variability is a problem for developing countries. Consumption of animal products is low, and there are few fruits and vegetables [19]. Furthermore, the staple plant foods consumed are poor in micronutrient content. The micronutrients they contain are also types that are difficult for the body to absorb [20]. The WHO recommends providing complementary foods for children starting at 6 months of age to meet the needs of calories, protein, and micronutrients needed for growth and development. Proper feeding during childhood is also crucial for preventing chronic degenerative diseases in the future [21]

This consumption factor is closely related to parenting by parents. According to UNICEF, parenting is defined as providing food, caring for children, guiding, and teaching children, which individuals and families do. The practice of giving food to children includes breastfeeding, quality supplementary food, food preparation and provision of nutritious food, child care, including caring for children when sick, immunization, giving supplements, bathing children, and so on [22] The dominant factor that causes malnutrition is inappropriate behavior among the community in selecting and providing food to family members, especially children. Therefore, various activities must be carried out to provide proper nutrition (Feeding) and care (caring) to achieve good nutritional status. Feeding and caring through mothers' parenting to their children will positively and negatively affect their growth and development [23].

2. Relationship between factors of breastfeeding and nutritional status

The breastfeeding factor explains the weak relationship with nutritional status $(r=-0.015)$, or the factor of breastfeeding of $0.03 \%$ explained the nutritional status factor. The remaining $99.97 \%$ was defined by a unique factor, namely, error factor (d1). It causes the consumption factor to be further analyzed in the model structure analysis. In other words, the relationship between breastfeeding factors could be analyzed directly with nutritional status [10]. 
Breastfeeding is a priority given to children. Previous research shows that breastfeeding has a significant relationship with the incidence of stunting in children under five [24]. Breastfeeding is identified as an affordable maternal health behavior in protecting children against stunting. Breastfeeding can reduce the risk of 0.5 times the incidence of stunting. Breastfeeding for children is given at least until the age of 6 months to minimize the incidence of stunting in children [25].

Research that analyzed data from Riskesdas in 2013 found that exclusive breastfeeding was protective against stunting in children. However, the results were not significant, both for exclusive breastfeeding $>6$ months and exclusive breastfeeding for 4- $<6$ months. The multivariable analysis results show that the variables associated with stunting in children aged 6-23 months in Indonesia are birth weight and household economic status. In the selected logistic regression equation model, children with low birth weight $(<2,500 \mathrm{~g})$ have a 1.77 times higher risk of becoming stunted compared to children born with normal weight $(>2,500 \mathrm{~g})$ [26].

Weaning/stopping breastfeeding at an early age will impact the nutritional status of the child. Some of the factors that cause early weaning are the working mother's status, education level, and residence place [27]. Weaning has a significant role in determining a child's nutritional status. Poor weaning practices during infancy and toddlerhood can lead to malnutrition, contribute to cognitive and social growth and development disorders, poor school performance, and decreased productivity in the future [28].

\section{Conclusion}

The stunting model in children under five was associated with the analysis of factors of consumption and breastfeeding. Based on the confirmatory analysis, consumption and breastfeeding factors can be further analyzed with structural analysis models. The strength of the relationship between consumption and toddler stunting was relatively weak $(r=0.052)$. The strength of the relationship between breastfeeding and toddler stunting was relatively weak $(r=-0.015)$. To prevent nutritional problems, the factors that need to be considered were consumption and breastfeeding. Other things that also need attention were the factors that cause the low level of consumption. It was particularly protein, and the things cause the mother's behavior to perform early breastfeeding practices and provide exclusive breastfeeding.

\section{References}

1. Owino V, Ahmed T, Freemark M, Kelly P, Loy A, Manary M, et al. Environmental enteric dysfunction and growth failure/stunting in global child health. Pediatrics. 2016;138(6):e20160641. https:// doi.org/10.1542/peds.2016-0641

PMid:27940670

2. Local Burden of Disease Child Growth Failure Collaborators Mapping child growth failure across low-and middle-income countries. Nature. 2020;577(7789):231-4. https://doi. org/10.1038/s41586-019-1878-8

PMid:31915393

3. de Onis M, Branca F. Childhood stunting: A global perspective Matern Child Nutr. 2016;12 Suppl 1:12-26. https://doi. org $/ 10.1111 / \mathrm{mcn} .12231$

PMid:27187907

4. Balitbangkes. Laporan Nasional Riskesdas 2013. Jakarta: Balitbangkes; 2014.

5. Mahmudiono T, Sumarmi S, Rosenkranz RR. Household dietary diversity and child stunting in East Java, Indonesia. Asia Pac J Clin Nutr. 2017;26(2):317-25.

PMid:28244712

6. Alamu EO, Gondwe T, Eyinla TE, Maziya-Dixon B. Assessment of dietary diversity of mothers and children of 6-24 months from eastern and Southern provinces of Zambia. J Nutr Metab. 2019;2019:1049820. https://doi.org/10.1155/2019/1049820

7. Nachvak SM, Sadeghi O, Moradi S, Esmailzadeh A, Mostafai R. Food groups intake in relation to stunting among exceptional children. BMC Pediatr. 2020;20:1-8. https://doi.org/10.1186/ s12887-020-02291-7

8. Sirasa F, Mitchell L, Harris N. Dietary diversity and food intake of urban preschool children in North-Western Sri Lanka. Matern Child Nutr. 2020;16:1-17. https://doi.org/10.1111/mcn.13006

9. Syeda B, Agho K, Wilson L, Maheshwari GK, Raza MQ. Relationship between breastfeeding duration and undernutrition conditions among children aged 0-3 years in Pakistan. Int $J$ Pediatr Adolesc Med. 2020;8:10-7. https://doi.org/10.1016/j. ijpam.2020.01.006 PMid:33718571

10. Campos AP, Vilar-Compte M, Hawkins SS. Association between breastfeeding and child stunting in Mexico. Ann Glob Health. 2020;86(1):145. https://doi.org/10.5334/aogh.2836 PMid:33262934

11. Sari N, Manjorang MY, Zakiyah, Randell M. Exclusive breastfeeding history risk factor associated with stunting of children aged 12-23 months. Kesmas. 2021;16:28-32. https:// doi.org/10.21109/kesmas.v16i1.3291

12. Sirajuddin, Asbar R, Nursalim, Tamrin A. Breastfeeding practices can potential to prevent stunting for poor family. Enferm Clín. 2020;30 Suppl 4:13-7. https://doi.org/10.1016/j. enfcli.2020.02.007

PMid:32545030

13. Kemenkes RI. Laporan Nasional Riset Kesehatan Dasar 2018 Jakarta: Kementerian Kesehatan Republik Indonesia; 2019.

14. TNP2K. 100 Kabupaten/Kota Prioritas Untuk Intervensi Anak Kerdil (Stunting). Jakarta: Tim Nasional Percepatan Penanggulangan Kemiskinan (TNP2K); 2017.

15. Kemenkes RI. Angka Kecukupan Gizi yang Dianjurkan Bangsa Indonesia. Jakarta: Direktorat Bina Gizi dan Kesehatan Ibu dan Anak; 2014.

16. Khamis AG, Mwanri AW, Ntwenya JE, Kreppel K. The influence of dietary diversity on the nutritional status of children between 
6 and 23 months of age in Tanzania. BMC Pediatr. 2019;19:1-9. https://doi.org/10.21203/rs.2.16657/v3

17. Modjadji P, Molokwane D, Ukegbu PO. Dietary diversity and nutritional status of preschool children in North West Province, South Africa: A cross sectional study. Children (Basel). 2020;7(10):174. https://doi.org/10.3390/children7100174 PMid:33050271

18. Kunto YS, Bras H. Ethnic group differences in dietary diversity of school-aged children in indonesia: The roles of gender and household SES. Food Nutr Bull. 2019;40(2):182-201. https:// doi.org/10.1177/0379572119842993 PMid:31046454

19. Ahmad I, Khalique N, Khalil S, Urfi U, Maroof M. Dietary diversity and stunting among infants and young children: A cross-sectional study in Aligarh. Indian J Community Med. 2018;43(1):34-6. https://doi.org/10.4103/ijcm.ijcm_382_16 PMid:29531436

20. Berrazaga I, Micard V, Gueugneau M, Walrand S. The role of the anabolic properties of plant-versus animal-based protein sources in supporting muscle mass maintenance: A critical review. Nutrients. 2019;11(8):1825. https://doi.org/10.3390/ nu11081825

PMid:31394788

21. World Health Organization. WHA Global Nutrition Targets 2025 : Stunting Policy Brief. Geneva: World Health Organization; 2014. Available from: https://www.who.int/nutrition/topics/globaltargets_ stunting_policybrief.pdf. [Last accessed on $2021 \mathrm{Mar}$ 16].

22. Tessema M, Gunaratna NS, Brouwer ID, Donato K, Cohen JL, McConnell $\mathrm{M}$, et al. Associations among high-quality protein and energy intake, serum transthyretin, serum amino acids and linear growth of children in Ethiopia. Nutrients. 2018;10(11):1776. https://doi.org/10.3390/nu10111776

PMid:30453477

23. Uwiringiyimana V, Ocké MC, Amer S, Veldkamp A. Predictors of stunting with particular focus on complementary feeding practices: A cross-sectional study in the northern province of Rwanda. Nutrition. 2019;60:11-8. https://doi.org/10.1016/j. nut.2018.07.016

PMid:30508763

24. Barir B, Murti B, Pamungkasari EP. The Associations between exclusive breastfeeding, complementary feeding, and the risk of stunting in children under five years of age: A path analysis evidence from Jombang East Java. J Matern Child Health. 2019;4:486-98. https://doi.org/10.26911/thejmch.2019.04.06.09

25. Anindya IG, Salimo H, Dewi YL. Relationship between exclusive breastfeeding and stunting in children aged 6 months old. In: The $6^{\text {th }}$ International Conference on Public Health; 2019. p. 213. https://doi.org/10.26911/the6thicph.03.71

26. Paramashanti $\mathrm{BA}$, Hadi $\mathrm{H}$, Exclusive breastfeeding practice was not related with stunting in young children 6-23 months in Indonesia. J Gizi Diet Indones. 2015;3:162-74. https://doi. org/10.21927/ijnd.2015.3(3).162-174

27. Pambudi J, Christijan R. Early weaning practice in correlation to social-economic and residential geography. Penelit Gizi Makanan. 2017;40:87-94. https://doi.org/10.22435/pgm. v40i2.7666.87-94

28. Vyas S, Kandpal SD, Semwal J, Chauhan SN. Trends in weaning practices among infants and toddlers in a hilly terrain of a newly formed state of India. Int J Prev Med. 2014;5(6):741-8. PMid:25013694 